\title{
KNOWLEDGE CONCERNING HPV AMONG ADOLESCENT UNDERGRADUATE NURSING STUDENTS ${ }^{1}$
}

\author{
Marislei Sanches Panobianco² Aline Daiane Faim de Lima³, Iácara Santos Barbosa Oliveira4, Thais de \\ Oliveira Gozzo
}

\footnotetext{
${ }^{1}$ Manuscript extracted from the monograph presented to University of São Paulo at Ribeirão Preto, College of Nursing in 2010.

${ }^{2}$ PhD in Public Health Nursing. Professor, Maternal-Infant Nursing and Public Health Department, University of São Paulo at Ribeirão Preto, College of Nursing. E-mail: marislei@eerp.usp.br

${ }^{3}$ RN, resident in Oncology Nursing, Federal University of São Paulo. São Paulo. Brazil. E-mail: alinedfaim@bol.com.br

${ }^{4}$ MSc in Public Health Nursing. RN, Municipal Emergency Department in São Sebastião do Paraíso, Minas Gerais, Brazil. E-mail: iacara.oliveira@yahoo.com.br

${ }^{5}$ PhD in Nursing. Professor, Maternal-Infant Nursing and Public Health Department, University of São Paulo at Ribeirão Preto, College of Nursing. E-mail: thaisog@eerp.usp.br
}

\begin{abstract}
The objectives of this descriptive and quantitative study were to identify and assess the level of knowledge of undergraduate nursing students concerning factors related to the sexually transmitted disease, Human Papillomavirus (HPV). A questionnaire was administered to 58 undergraduate nursing students at the University of Sao Paulo at Ribeirão Preto, College of Nursing. Data were analyzed using descriptive statistics through the Epi Info software. Results revealed that $46.6 \%$ of the participants are sexually active; $96.3 \%$ reported safe sex with the use of condoms, though $29.6 \%$ of them do not use one regularly. Regarding the forms of transmission, $69 \%$ reported knowing them, while only $20.7 \%$ reported knowledge of HPV's signs and symptoms. Additionally, 54.3\% of the adolescents reported not knowing what HPV can cause. Greater investment in health education directed to young individuals is required to promote health and prevent diseases, particularly those caused by the Human Papillomavirus. DESCRIPTORS: Knowledge. HPV. Adolescents. Nursing.
\end{abstract}

\section{O CONHECIMENTO SOBRE O HPV ENTRE ADOLESCENTES ESTUDANTES DE GRADUAÇÃO EM ENFERMAGEM}

\begin{abstract}
RESUMO: Este estudo objetivou identificar o nível de conhecimento entre adolescentes, estudantes de graduação em enfermagem, sobre os fatores relacionados à doença sexualmente transmissível - Papilomavírus Humano. Estudo descritivo, quantitativo, onde foi aplicado um questionário para 58 adolescentes, alunos da Escola de Enfermagem de Ribeirão Preto. Os dados da amostra foram analisados por meio da estatística descritiva, utilizando o programa Epi Info. Os resultados mostraram que 46,6\% dos participantes têm vida sexual ativa, 96,3\% relataram praticar sexo seguro usando preservativo, no entanto, $29,6 \%$ destes não fazem o uso regularmente. Entre as formas de transmissão, 69\% relataram conhecê-las, e apenas 20,7\% disseram saber alguns dos sinais e sintomas do vírus. Ainda, 54,3\% dos adolescentes disseram não saber o que o vírus pode causar. Deve haver um maior investimento na educação dos jovens para promoção à sua saúde e prevenção de doenças, em particular, aquelas causadas pelo Papilomavírus Humano.
\end{abstract}

DESCRITORES: Conhecimento. HPV. Adolescentes. Enfermagem.

\section{CONOCIMIENTO SOBRE HPV ENTRE JÓVENES ESTUDIANTES DE PREGRADO EN ENFERMERÍA}

RESUMEN: Estudio descriptivo y cuantitativo que identificó y evaluó el conocimiento de los estudiantes de pregrado en enfermería sobre los factores relacionados a la enfermedad de transmisión sexual: Virus del Papiloma Humano. Se administró un cuestionario a 58 estudiantes de la Escuela de Enfermería de Ribeirão Preto-Universidad de São Paulo. Los datos fueron analizados por medio de estadística descriptiva y el software Epi Info. Los resultados mostraron que 46,6\% de los encuestados son sexualmente activos, $96,3 \%$ informaron practicar sexo seguro con uso del condón, sin embargo, 29,6\% de ellos no lo utilizan con regularidad. El $69 \%$ relataron conocer las formas de transmisión y sólo el 20,7\% afirmaron saber señales y síntomas del virus. El 54,3\% refiere no saber lo que el virus puede causar. Debe haber mayor inversión en la educación de los jóvenes para promoción de la salud y prevención de enfermedades, especialmente las causadas por Virus del Papiloma Humano.

DESCRIPTORES: Conocimiento. HPV. Adolescentes. Enfermería. 


\section{INTRODUCTION}

The Human Papillomavirus (HPV) belongs to the Papovavirus or Papovaviridae family and is responsible for a sexually transmitted infection known as condylomata acuminata, genital warts, or cockscomb-like warts. There are about 120 types, 36 of which infect the genital tract. ${ }^{1}$

HPV transmission occurs by direct contact with infected skin and genital HPV occurs through sexual intercourse, possibly causing lesions on the vagina, cervix, penis or anus. There are studies showing the rare presence of the virus on the skin, larynx (voice box) or esophagus. ${ }^{2}$

Due to this virus' role in cancer etiology and data provided by the World Health Organization (WHO) on the incidence and mortality accruing from malignant tumors, it is estimated that this virus is linked to the development of at least $10 \%$ to $15 \%$ of neoplasias affecting humans. ${ }^{3}$

The HPV diagnosis is achieved by the identification of warts, which, whenever present, should be removed. In cases in which warts are not visible to the naked eye, the diagnosis is reached through peniscopy in men and colposcopy in women. These exams are considered the best tests to reach a diagnosis, since most lesions $(80 \%)$ are found through them; biological material is collected for both. ${ }^{4}$

The subclinical diagnosis of precancerous lesions caused by HPV, is accomplished through a preventive Pap smear test and is confirmed through molecular diagnostic laboratory exams, such as the hybrid capture test. ${ }^{2}$

These data clearly show the importance of preventing HPV infection, mainly through interrupting the chain of infection, that is, preventing the infection itself and eliminating the lesions caused by the virus. Information concerning the risk factors associated with sexual behavior provided to the population through educational actions is important to controlling transmission. The use of condoms during sexual intercourse is one of the main ways to reduce HPV infection, though it does not totally eliminate the risk. ${ }^{5}$

Vaccines are also very efficient in preventing HPV infection, especially when administered at the beginning of sexual life, because preadolescents and adolescents are sexually immature and possess good immune responses. ${ }^{6}$ These vaccines do not change the course of a preexisting disease, but protect women from strains to which they have not been exposed. Since the infection is acquired after sexual activity has started, the vaccine is recommended for women who have not initiated sexual life. The recommended age is 12 years old, but the vaccine can be administered from the age of nine. ${ }^{7}$

In recent decades, sexual activity has started increasingly early, an important cause for the increased prevalence of HPV and the lesions it causes. Sexually active adolescents present the highest rates of HPV incidence and prevalent infections, ranging from $50 \%$ to $80 \%$ of infections, two to three years after sexual life has started. ${ }^{8}$

During adolescence, sexual intercourse occurs with a greater number of partners, which contributes to increased rates of Sexually Transmitted Diseases (STDs). Hence, if not prevented, this pathology may be disseminated from one adolescent to another, increasing the number of affected individuals and leading to a public health problem. ${ }^{9}$

Combined with the magnitude of the HPV infection problem is a lack of knowledge about the virus, its signs and symptoms, and its relationship with cervical cancer and forms of its transmission.

Lack of appropriate information concerning $\mathrm{HPV}$ can lead to misconceptions that negatively interfere in the behavior of those affected by the virus and people who belong to the social context of those affected. Usually, people only learn about HPV when they have already been infected and seek treatment. ${ }^{10}$

Studies conducted with adolescents show they hold misconceptions about HPV, such as: $\mathrm{HPV}$ is a disease that can be acquired through blood transfusions, by sharing needles and injectable syringes, or by living together with infected individuals. ${ }^{11}$ Other misconceptions include the belief that HPV is only transmitted from men to women and that it is a disease acquired by promiscuous women. ${ }^{10}$ Informing and sensitizing adolescents about HPV and the associated risks, as well as about prevention, can contribute to reducing HPV infection. ${ }^{12}$

Even though there is no evidence that condoms are efficient in the prevention of HPV transmission, ${ }^{13}$ their use reduces the chance of infection. Additionally, safe sex coupled with a change in sexual behavior is an important strategy to control the chain of transmission of other STDs and HIV. ${ }^{1}$ 
This study's objective was to identify the level of knowledge concerning factors related to STDs and HPV, such as symptoms, transmission, and prevention, among adolescents and nursing undergraduate students, as well as to identify the source of such knowledge and whether sexually active individuals practice safe sex.

The authors of a study conducted with nursing students stress the importance of providing guidance concerning sexuality because it contributes to their professional education and also to their personal lives, minimizing taboos and clarifying doubts, since even health workers are subject to being infected and transmitting STDs. ${ }^{14}$

In this context, nursing workers are professionals concerned with health education actions and can work with young individuals in different sectors and social segments, seeking to prevent the risk of exposure. ${ }^{15}$

In addition to all these considerations, studying and working in a nursing school, which is the case of this study's authors, motivates one to identify the reality of students in relation to HPV knowledge and the prevention measures they use. The results of this scientific investigation can reveal new ways to provide tools to these individuals and guide them to care for the population at risk of acquiring HPV.

\section{METHOD}

The definition of an adolescent adopted in this study is an individual aged between 10 and 19 years old, according to the definition provide by the WHO. ${ }^{16}$

This study was approved by the Institutional Review Board at the University of São Paulo at Ribeirão Preto, College of Nursing (Process No. 1224/2010).

A descriptive study was conducted with undergraduate students attending the University of São Paulo at Ribeirão Preto, College of Nursing who met the following inclusion criteria: being a female student up to the age of 19 years old, formally enrolled in either the Nursing Bachelors or Teaching Degree Programs, and being present at the time of data collection.

Data were collected through a questionnaire developed by the authors and based on related scientific literature. Three health professionals working with adolescents and HPV assessed the questionnaire before its application. The objective, multiple-choice questions addressed knowledge concerning HPV and personal information with the exception of the participants' names. The questionnaire addressed definitions, how HPV is transmitted, and how transmission can be prevented. One of the researchers applied the questionnaires immediately before classes. The questionnaires were distributed inside envelopes and returned inside closed envelopes to avoid students being identified. Free and informed consent forms were also distributed together with the questionnaires. They contained information concerning the study and required the signatures of the participants.

Data from the sample were organized in electronic spreadsheets in Excel 2007 for Windows, then exported to the Epi Info program and analyzed using descriptive statistics.

\section{RESULTS}

A total of 58 female students participated in the study. When distributing the participants into age groups, we verified that most $(20.7 \%)$ were 18 years old and the greatest concentration of students was in the Bachelor's program $(72.4 \%) ; 87.9 \%$ were freshmen. Additionally, $98.3 \%$ were single and most were Catholic (56.9\%) (Table 1).

Table 1 - Distribution of adolescents according to age, marital status, religion, undergraduate program, and year of the program. Ribeirão Preto, SP, Brazil 2010

\begin{tabular}{lccr}
\hline \multicolumn{1}{c}{ Variables } & Categories & $\mathbf{n = 5 8}$ & \multicolumn{1}{c}{$\%$} \\
\hline \multirow{3}{*}{ Agelyears } & 17 & 23 & 39.7 \\
& 18 & 12 & 20.7 \\
Marital status & 19 & 23 & 39.7 \\
& Single & 57 & 98.3 \\
& Married & 1 & 1.7 \\
Religion & Catholic & 33 & 56.9 \\
& Spiritist & 10 & 17.2 \\
& None & 10 & 17.2 \\
Program & Other & 5 & 8.6 \\
& Bachelor & 42 & 72.4 \\
Year of the program & Freshman & 51 & 87.9 \\
& Sophomore & 7 & 12.1 \\
\hline
\end{tabular}


In regard to the adolescents' sexual lives, 27 out of the 58 interviewees reported an active sexual life, $59.2 \%$ of these continued sexual intercourse for more than a year and $55.5 \%$ practiced it regularly. In terms of safe sex, $96.3 \%$ of 27 interviewees reported the use of condoms, though $29.6 \%$ of these reported their occasional use (Table 2).

Table 2 - Distribution of adolescents according to time since sexual activity was initiated, practice and frequency of safe sex. Ribeirão Preto, SP, Brazil 2010

\begin{tabular}{llrc}
\hline Variables & Categories & n=27 & \% \\
\hline Time since sexual life & Up to 1 year & 11 & 40.7 \\
started & More than 1 year & 16 & 59.2 \\
& Yes & 26 & 96.3 \\
Safe sex & No & 1 & 3.7 \\
& Always & 18 & 66.6 \\
Frequency of safe sex & Sometimes & 8 & 29.6 \\
\hline
\end{tabular}

In regard to knowledge about what the acronym HPV stands for, 35 (60.3\%) adolescents reported being aware of its meaning. When they were asked about how HPV is transmitted, 69\% reported knowledge about forms of transmission, and only $20.7 \%$ reported knowledge of some HPV signs and symptoms (Table 3 ).

Table 3 - Distribution of adolescents according to knowledge about HPV, source of information about HPV, and knowledge about the consequences of HPV infection. Ribeirão Preto. SP, Brazil 2010

\begin{tabular}{llrr}
\hline Variables & Categories & $\mathbf{n = 3 5}$ & \multicolumn{1}{c}{$\%$} \\
\hline \multirow{2}{*}{ Meaning of HPV } & Yes & 35 & 60.3 \\
& No & 23 & 39.7 \\
& Home & 4 & 11.4 \\
& College & 7 & 20 \\
Source of information & Friends & 5 & 14.3 \\
& Internet & 4 & 11.4 \\
Know the conse- & Others & 15 & 42.9 \\
quences & Yes & 16 & 45.7 \\
& No & 19 & 54.3 \\
\hline
\end{tabular}

The 23 adolescents who reported a lack of knowledge concerning the meaning of the acronym HPV also did not know the consequences of the virus. A total of $42.9 \%$ of the 35 adolescents who reported being aware of the meaning of HPV obtained such knowledge through information provided by gynecologists and in lectures addressing the topic; $20 \%$ reported they acquired knowledge in college. Yet, $54.3 \%$ of the adolescents did not know the consequences of HPV (Table 3).

\section{DISCUSSION}

This study's results corroborate those found by other authors concerning late initiation of sexual life as a consequence of the differentiated project of life chosen by adolescents who have the goal to complete higher education. Hence, perhaps the objective to enter a public university, give priority to education, having a greater concern for the future, and the responsibilities inherent to a college student, have favored such a situation. ${ }^{4,17}$

It is important, however, to note that the number of adolescents who initiate sexual life in this period of their lives is higher than that observed in past decades. The media encourages early initiation in sexual life, but does not always reinforce the importance of safe sex, a lapse that favors HPV infection, a variety of STDs, and consequently cervical cancer. The Brazilian Ministry of Health cautions that sexual life, initiated during adolescence, contributes to early and repeated pregnancies during this phase of life. Consequently, infection by HPV and its consequences are also among such risks. ${ }^{18}$

The adolescents interviewed in this study were aware that condoms are synonymous with safe sex and most report their use during sex. However, a large part of them reveal their only occasional use, indicating that many instances of sexual intercourse occur without protection. Adding this information to the sample's characteristics, i.e. single adolescents with occasional sexual activity and partners, leads us to conclude these adolescents are exposed to an important risk factor for the transmission of HPV and other STDs, in addition to the occurrence of unplanned pregnancies.

In this sense, studies show that adolescents in general know that condoms prevent diseases and pregnancy, however they do not use them, 
a fact that shows the existence of a considerable gap between level of knowledge and the effective use of condoms. ${ }^{19-20}$

A study conducted in ten schools in Rio de Janeiro, RJ, Brazil with 945 students aged from 13 to 21 years old, shows that, even though $94 \%$ of them recognize the protection conferred by condoms, only $34 \%$ reported their regular use. The study's authors associate this risky behavior with a low level of knowledge concerning STDs. ${ }^{21}$

Adolescents indicated the disadvantages of using condoms, among them: discomfort and diminished sensitivity. Additionally, they use condoms only as a contraceptive method, not heeding the fact that condoms also prevent STDs. ${ }^{22}$

These statements indicate there is a deficit between knowledge and information received, which leads to a gap in the educational process aiming to prevent STDs among adolescents. These data became apparent when the participants were asked about their knowledge concerning HPV, its transmission, signs, symptoms and consequences. They recognize HPV as an STD but more than half do not know what its signs and symptoms are nor are aware of its consequences, such as cervical cancer.

Results from similar studies corroborate these statements, such as one conducted with a group of adolescents who were asked about the main STDs. The authors verified that AIDS was frequently mentioned but other STDs and HPV infection were seldom mentioned by these adolescents. ${ }^{23}$

In regard to cervical cancer, studies show that the cervix transformation zone, in which columnar cells can undergo squamous metaplasia, is more exposed during adolescence than in adult life. This area is more susceptible to infection by sexually transmitted pathogenic agents, including HPV, and is the area where most precursor lesions and cervical carcinomas originate. A lower production of cervical mucus, which can act as a protective barrier against infectious agents, associated with a larger area of cervical ectopy in adolescents, is a biological risk factor for infection by pathogenic agents, including HPV. ${ }^{24}$

A crucial factor that should be taken into account is that precursor cervical cancer lesions among adolescents involve not only biological factors but also cultural and social factors. A study addressing adolescents reports there are many myths, preconceptions, and misconceptions involving sexuality. Poor access to knowledge within the family concerning sexuality and how to prevent cervical cancer should be compensated for by information provided in classrooms and in health education campaigns. ${ }^{20}$

Most of the study's adolescents who reported knowledge about HPV reported they acquired such knowledge in consultations with gynecologists and during undergraduate studies. Another study, also conducted with college students, shows that a small percentage of the sample reported the influence of family members in the choice to use a contraceptive method. This reinforces the idea that there are still barriers in the dialog established between parents and children in regard to sexuality issues. ${ }^{4}$

The lack of information among adolescents results from the family neglecting its role in constructing a healthy sexuality. A lack of dialog among families, and even parents unprepared to keep an open conversation and to provide guidance to their children, is a situation that ends up affecting the attitudes of adolescents. Adolescents often seek information from friends and other sources of information that may not be reliable, based on beliefs and lack of knowledge, which may confuse and hinder the preventive process and the education of adolescents toward HPV and other STDs. ${ }^{9}$

Even though college students are observed to start sexual life later in life, the Brazilian Ministry of Health states that the number of adolescents initiating sexual activity in this phase of life is increasingly higher in last decades. The media encourages early sexual activity but not always reinforce the importance of safe sex, which favors infection of HPV and its consequences. ${ }^{2}$

The family, school and government have complementary and essential roles in the education of adolescents, instructing them to have responsible attitudes in relation to their sexuality, protecting them from physical and mental harm and, especially in this case, helping them avoid becoming infected by HPV or other STDs or facing unplanned pregnancies.

\section{CONCLUSION}

The adolescents participating in this study were enrolled in an undergraduate program in the health field, thus, we expected that most 
would be appropriately informed about the HPV signs and symptoms, and the relationship between HPV and cervical cancer. This study shows that a portion of them do not even know what the acronym HPV stands for or what its consequences are or how the virus is transmitted; less that half know its signs and symptoms. Therefore, a greater investment is required in the education of young individuals to promote health and prevent diseases, especially STDs, mainly HPV.

This study implies the need to find new ways to enable students to acquire better knowledge about the consequences of being infected by HPV and to instruct them to provide care to the population at risk of acquiring the virus.

The study's limitations include two issues that may have interfered in the results: 1) the study was conducted with undergraduate students from the health field who have greater access to information concerning the studied topic; 2) the interviewed adolescents had not yet been enrolled in the course that has the content concerning women's health, in which such issues are addressed in more detail.

\section{REFERENCES}

1. Ministério da Saúde (BR). Departamento de Atenção Básica. Cadernos de Atenção Básica. HIV/aids, Hepatites e outras DST. Brasília (DF): Ministério da Saúde; 2006.

2. Ministério da Saúde (BR). Instituto Nacional do Câncer. Comitê permanente de acompanhamento da vacina do HPV. Brasília (DF): Ministério da Saúde; 2010.

3. Carvalho JJM. Falando sobre o HPV. São Paulo (SP): Instituto Garnet; 2003.

4. Alves AS, Lopes MHBM. Uso de métodos anticoncepcionais entre adolescentes universitários. Rev Bras Enferm. 2008 Mar-Abr; 61(2):170-7.

5. Ministério da Saúde (BR). Secretaria de Vigilância em Saúde. Doenças Sexualmente Transmissíveis (DST): manual de bolso. Brasília (DF): Ministério da saúde; 2006.

6. Nadal LRM, Nadal SR. Indicações da vacina contra o Papilomavírus Humano. Rev Bras Coloproctol. 2008 Jan-Mar; 28(1):124-6.

7. Rogers JL, Lois LJ, Luesley DM. Vaccines against cervical cancer. Curr Opin Oncol. 2008 Set; 20(5):570-4.

8. Roteli-Martins CM, Longatto AF, Hammes LS, Derchain SFM, Naud P, Matos JC. Associação entre idade ao início da atividade sexual e subsequente infecção por papilomavírus humano: resultados de um programa de rastreamento brasileiro. Rev Bras Ginecol Obstet. 2007 Nov; 29(11):580-7.

9. Oria M, Alves MDS. Adolescente com papiloma vírus humano no contexto familiar. Rev Enferm UERJ. 2004 Abr; 12(1):44-8.

10. Sousa LB, Pinheiro AKB, Barroso MGT. Ser mulher portadora do HPV: uma abordagem cultural. Rev Esc Enferm USP. 2008 Dez; 42(4):737-43.

11. Conti FS, Bortolin S, Kulkamp CI. Educação e promoção à saúde: comportamento e conhecimento de adolescentes de colégio público e particular em relação ao papilomavírus humano. DST. J Bras Doenças Sex Transm. 2006 Out; 18(1):30-5.

12. Pedrosa ML, Mattos IE, Koifman RJ. Lesões intraepiteliais cervicais em adolescentes: estudo dos achados citológicos entre 1999 e 2005, no Município do Rio de Janeiro, Brasil. Cad Saúde Pública. 2008 Dez; 24(12):2881-90.

13. Manhart LE, Koutsky LA. Do condoms prevent genital HPV infection, external genital warts, or cervical neoplasia?: a meta-analysis. Sex Transm Dis. 2002 Nov; 29: 725-35.

14. Brêtas JRS, Ohara CVS, Querino ID. Orientação sobre sexualidade para estudantes de enfermagem. Acta Paul Enferm. 2008; 21(4):568-74.

15. Beserra EP, Pinheiro PNC, Barroso MGT. Ação educativa do enfermeiro na prevenção de doenças sexualmente transmissíveis: uma investigação a partir das adolescentes. Esc Anna Nery Rev Enferm. 2008 Set; 12(3):522-8.

16. World Health Organization. Pregnancy and abortion in adolescence: report of a WHO Meeting. Geneva (CH): Technical Report Series; 1975.

17. Pirotta KCM. Não Há guarda-chuva contra o amor: estudo do comportamento reprodutivo e seu universo simbólico entre jovens universitários. Ciênc Saúde Coletiva. 2002 Jan-Fev; 5(26):232-7.

18. Ministério da Saúde (BR). Secretaria de Atenção à Saúde. Marco teórico e referencial saúde sexual e saúde reprodutiva de adolescentes e jovens. Brasília (DF): Ministério da Saúde; 2006.

19. Taquette SR, Vilhena MM, Paula MC. Doenças sexualmente transmissíveis na adolescência: estudo de fatores de risco. Rev Soc Bras Med Trop. 2004 Mai-Jun; 37(3):210-4.

20. Cirino FMSB, Nichiata LYI, Borges ALV. Conhecimento, atitude e práticas na prevenção do câncer de colo uterino e HPV em adolescentes. Esc Anna Nery. 2010 Jan-Mar; 14(1):126-34.

21. Trajman A, Belo MT, Teixeira EG, Dantas VCS, Salomão FM, Cunha AJLA. Conhecimento sobre DST/AIDS e comportamento sexual entre estudantes do ensino médio no Rio de Janeiro, Brasil. Cad Saúde Pública. 2003 Fev; 19(1):127-33.

22. Bandeira VMP, Diógenes MAR. O uso do preservativo masculino e feminino entre alunos 
de enfermagem da universidade de Fortaleza. Rev Enferm UERJ. 2006 Jan-Mar; 14(1):74-9.

23. Romero KT, Medeiros EHGE, Vitalle MSS, Wehba J. O conhecimento das adolescentes sobre questões relacionadas ao sexo. Rev Assoc Med Bras. 2007 Fev; 53(1):14-9.
24. Longatto AF, Etlinger D, Gomes NS, Cruz SV, Cavalieri MJ. Frequência de esfregaços cérvicovaginais anormais em adolescentes e adultas: revisão de 308.630 casos. Rev Inst Adolfo Lutz. 2003; 62(1):31-4. 